\title{
The Credibility of Marian Apparitions. The Gietrzwałd Context
}

Paweł Rabczyński*

rabczynski@o2.pl https://doi.org/10.31192/np.17.3.8

UDK / UDC: 2-587.5:27-312.47(438Gietrzwald)

Izvorni znanstveni članak / Original scientific paper

Primljeno / Received: 17. lipnja 2019. / Jun 17, 2019

Prihvaćeno / Accepted: 20. listopada 2019. / Oct 20, 2019

The year 2017 marks the 140 th anniversary of Marian apparitions in Gietrzwatd, a small village situated in southern Warmia. On 11 September 1977, the revelations in Gietrzwatd received official approval of the Church. The message imparted to the seers by the Mother of God may be encapsulated in three sentences: I am the Blessed Virgin Mary Immaculately Conceived; I wish you recite the rosary every day; Do not be sad for I will always be with you. Marian apparitions, classed as so-called private revelations, are aimed at bringing into actuality the Divine Revelation in a given historical period. The content of Marian apparitions usually boils down to a call for conversion, repentance or prayer. Thus, it provides an important impulse for Christian renewal, a return to Evangelical fervour and holiness. Upon consideration of the modern theological research, this article lists four main criteria for discerning the credibility of Marian epiphanies: a) Christological and ecclesiological reference; b) good fruits of the revelations; c) miracles and other supernatural phenomena; d) the credibility of people experiencing the revelations. Having analysed the invoked signs pointing to the authenticity of the revelations, the author concludes that Marian epiphanies in Gietrzwatd are fully credible.

Key words: public revelations, private revelations, Marian apparitions, Marian epiphanies, credibility of Marian epiphanies, criteria for discerning the credibility of Marian epiphanies.

\footnotetext{
* Paweł Rabczyński, PhD, Full Prof., University of Warmia and Mazury, Faculty of Theology, Olsztyn; Address: Ul. Hozjusza 15, 11-041 Olsztyn, Polen; ORCID ID: 0000-0002-8732-7019.
} 


\section{Introduction}

The year 2017 marks the $140^{\text {th }}$ anniversary of Marian apparitions in Gietrzwałd, a small village situated in the picturesque, hilly region of Warmia, $20 \mathrm{~km}$ to the south-west of Olsztyn. Gietrzwałd is inhabited mostly by Poles (Achremczyk S., 2002). Marian epiphanies took place between 27 June and 16 September 1877, including more than 160 epiphenomena. The seers were two girls: thirteen-year-old Justyna Szafryńska (1864-?) and twelve-year-old Barbara Samulowska (1865-1950) who beheld the apparitions at a large maple tree growing in the rectory garden. The first vision was experienced by Justyna alone, when she was going back from a class in religious education, at the time of the evening Angelus. The Mother of God would appear when she was saying the rosary, first once, and then three times a day. On 1 July, Justyna had a vision at home and on 8 September, Mary appeared to the seers at a spring (Hipler F., 2017; Obłąk J., 1977, p. 7-73; Pawluk T., 1977, p. 75-107; Kopiczko A., 2003, p. 29-37; Tomczyk B. et Ryłko S., 1999; Kasjaniuk G., 2017; Rabczyński P., 2018, p. 193-213). Based on source literature and the statements of competent Church authorities, the author does not include the visions of Elżbieta Bilitewska and Katarzyna Wieczorek within the scope of Gietrzwałd revelations, regarding them as incredible.

The $100^{\text {th }}$ anniversary of the apparitions was celebrated with the Mariological and Marian Congress, held in Olsztyn and Gietrzwałd from 24 to 26 June 1977, where the Marian epiphanies in Gietrzwałd were discussed by historians, canonists, and theologians. On 25 June 1977, the Congress adopted the following resolution:

$»$ The Fourth Polish Nationwide Mariological and Marian Congress asks the Bishop of Warmia to confirm, by virtue of his ordinary Pastoral Office, the 100-year-old worship of Our Lady of Gietrzwałd and the credibility of the apparitions which provide its foundation" (Kongres Mariologiczny i Maryjny, 1977, p. 246).

On 11 September 1977, Marian apparitions in Gietrzwałd received official approval of the Church. Bishop Józef Drzazga of Warmia (1914-1978) (Kopiczko A., 2008, p. 457-464) issued a decree saying (1977, p. 5):

»We hereby approve the devotion to Our Lady's Apparitions in Gietrzwałd as not contradicting Christian faith and morality, whose miraculous and divine nature cannot be excluded.»

In the decree, the head of the Warmian Diocese listed three sentences of the highest importance, communicated by the Mother of God to the seers: I am the Blessed Virgin Mary Immaculately Conceived; I wish that you recite the rosary every day; Do not be sad, for I will always be with you. 
Blessed Honorat of Biała (1829-1916) (Bartoszewski G. et Prejs R., 1993) born Florentyn Wacław Koźmiński, was a Polish priest of the Capuchin Order, a known confessor, pedagogue, writer and founder of many religious congregations - including the Servant Sisters of the Most Blessed Virgin Mary Immaculate, genetically related to Gietrzwałd apparitions. Fascinated by the message of the apparitions, Blessed Honorat wrote in 1878 (one year after the last vision) in his notebook entitled Chwała Jezusowi przez Maryje Niepokalanie Poczęta [Glory to Jesus through Mary Immaculately Conceived] (Bartoszewski G., 1977, p. 349-363):

»Yet, it is unprecedented for the Mother of God to appear for such a long time, in a manner so accessible and so solemn as in Gietrzwałd. In the times of greater trials and tribulations, the Most Blessed Intercessor of the Church gives far clearer and more numerous proofs of her incessant care and concern in more frequent and extraordinary apparitions. Particularly striking are the three last apparitions in: Lourdes, Marpingen, and Gietrzwałd, largely similar in terms of manner wherein the Mother of God has traversed the whole Catholic Europe, saving the failing faith; admonishing and consoling, inspiring new life and religious fervour« (Koźmiński H., 2017, p. 70).

Indeed, in keeping with the intuition of Blessed Honorat, Gietrzwałd very soon came to be the spiritual capital of Warmia, an important centre of the pilgrimage movement, radiating the rosary; a place of spiritual transformation and moral conversion.

Importantly, the Beautiful Lady - as the girls described her - spoke in the Polish language, comprehensible to the seers. It was the era of the Partitions and the ruthless policy of Kulturkampf, whereunder Chancellor Otto von Bismarck sought to restrict the influence of the Catholic Church in the German Empire and to crush all things Polish. Thus, Gietrzwałd apparitions grew into a symbol of national awakening and renewal. »Lo and behold, Mary comes to the rescue of the Poles and accompanies them in the most saddening and difficult moments in history« (Obłąk J., 1957, p. 203-217; Bartoszewski G., 1977, p. 355-357).

For avoidance of doubt, it should be noted from the start that when the village of Gietrzwałd was founded in 1352, a parish church was established there by the Warmian Cathedral Chapter. In 1500, the church was consecrated to the Birth of the Most Blessed Virgin Mary by Suffragan Bishop Johann Wilde. Since the second half of the $16^{\text {th }}$ century, a miraculous painting of the Mother of God, worshipped by the faithful, has been featured in the high altar of the church. The representation is of the Hodogetria type ('she who shows the way'). Mary is holding the Infant on her left arm and, in the upper part of the icon, two angels are raising a banner saying: AVE REGINA CAELORUM AVE DOMINA ANGELORUM. The painting is commonly referred to as the image of Our Lady of Gietrzwałd. Indubitably, the apparitions of 1877 were 
a turning point in the history of its devotion. It was not weakened by Marian epiphanies, to the contrary, a prayer before Our Lady's painting became one of the main goals of the arriving pilgrims, together with a visit to the apparition chapel and the spring blessed by the Immaculate. It has remained so ever since (Nowak W., 1977, p. 109-134). On 10 September 1967, the painting of Our Lady of Gietrzwałd was crowned with papal crowns by Cardinal Stefan Wyszyński, Primate of Poland, assisted by Cardinal Karol Wojtyła, Bishop Józef Drzazga, ordinary of the Warmian diocese, and a large group of other bishops, presbyters and the faithful (Uroczystości maryjne w Gietrzwatdzie, 1968, p. 86-93).

Marian apparitions in Gietrzwałd are classed as so-called private revelations (Latin: apparitio). Catholic theology makes a clear distinction between such occurrences and a Public Revelation (Latin: revelatio Dei). However, they are not to be discounted. Oftentimes, private revelations become a motive of faith and make it stronger; they turn into important impulses for authentic religious renewal in a given historical period (Ratzinger J., 2000, p. 47).

Any attentive observer of religious life will assert that Marian apparitions have largely shaped the religiosity of Poles and other nations alike. Their importance and remarkable popularity are confirmed by the enormous number of publications, on sale in various bookshops, promoting messages and visions that are often surprising and not always approved by the Magisterium of the Catholic Church. Considering the keen interest stirred up by private apparitions, mostly Marian, and their ambiguity, the author decided to examine the abovementioned epiphenomena closely, with reference to theological hermeneutics. The issue of credibility of Marian apparitions will be presented as a case study of Gietrzwałd Marian epiphanies of 1877.

The article is divided into three parts. The first part gives a brief overview of the term 'Public Revelation' and of Marian apparitions. The second part outlines the main criteria for discerning the credibility of Marian epiphanies. While discussing the characteristic indicators of Marian apparitions and the main criteria of their credibility, the author invokes the example of the Gietrzwałd apparitions.

\section{The Public Revelation}

As mentioned above, Marian apparitions are classed as so-called private revelations, whereof they evidently constitute a substantial share. Theology distinctly differentiates those epiphenomena from the Public Revelation contained in the Scripture and the Tradition. The character of the distinction is both qualitative and formal (Rusecki M., 1994a, p. 40; Pawluk T., 1979, p. 284298). 
The Public Revelation is a supernatural action of God who reveals, exposes his existence, nature and saving will to man. The Revelation is public and universal since it is addressed to people of all times and all cultures. By his revelatory activity, God aims to summon and admit man to the full love of life in communion with the Persons of the Trinity, i.e. to salvation. On the part of man, the proper response to this unique invitation is fervent faith (Ledwon I. S. et Rusecki M., 2002, p. 859-871; Latourelle R., 1992, p. 1134-1189; Fisichella R., 1992, p. 66-101; Rusecki M., 1994b, p. 182-217; Schmaus M., 1989, Seckler M., 1981, p. 214-236).

At the centre of God's Revelation is the phenomenon of Jesus Christ; His Person, teachings, acts. The entire life of Jesus Christ was revelatory, and thus - salvific in character. From the theological viewpoint, He is A and $\Omega$ of history, an explanation of the sense of the entire created world, men, and their history (Bartnik Cz. S., 1999, p. 729-730). It is in Him that the Divine truth was fully and ultimately revealed (see: Acts 4:12; Phil. 2:9-11; Heb. 1:1-2). This implies that in course of history, God will not make any fuller revelation (Sobór Watykański II, $1986^{3}$ a, No. 4, p. 351); Kongregacja Nauki Wiary, 2001, No. 5-8, p. 12-16; Rabczyński P., 2005, p. 69-70).

Cardinal Joseph Ratzinger explains:

"The term 'public Revelation' refers to the revealing action of God directed to humanity as a whole and which finds its literary expression in the two parts of the Bible: the Old and New Testaments. It is called 'Revelation' because in it God gradually made himself known to men, to the point of becoming man himself, in order to draw to himself the whole world and unite it with himself through his Incarnate Son, Jesus Christ. [...] Because God is one, history, which he shares with humanity, is also one. It is valid for all time, and it has reached its fulfilment in the life, death and resurrection of Jesus Christ. In Christ, God has said everything, that is, he has revealed himself completely, and therefore Revelation came to an end with the fulfilment of the mystery of Christ as enunciated in the New Testament« (2000, p. 47).

It is generally assumed that the Public Revelation - which everybody is bound to accept - was completed during the Apostolic period. The Apostles, who enjoyed special assistance of the Holy Spirit, continued to experience the Revelation to elucidate the mystery of Christ, to proclaim the previously obscure meaning of words and acts of the Saviour (De Candido L. M., 2004, p. 7789). However, though the Public Revelation ended with the passing of the last Apostle, it has continued and remained available throughout history thanks to the Church. Christ established the Church as a historical quasi-prolongation of His own existence. The Church continues salvation history at its last stage, providing people of all times with a chance of reaching salvation. Nowadays, by the will of Jesus, the Revelation is upheld in the Church, through and within which it is imparted (cf. John 16:12-14) (Rusecki M., 1994b, p. 218; Schmitz J., 
1991, p. 156-160; Ratzinger J., 1970, p. 50; Rahner K., 1987, p. 280). Thus, both interpretation and explanation of the Divine Revelation are constitutive tasks of the Church. In the changing world, the community of the faithful is obliged to undergo continuous modernisation (the aggiornamento of the Second Vatican Council) to make the Divine Revelation, whereof it is the holder and the messenger, comprehensible to all people of all times (Sobór Watykański II, ${ }^{3} 1986 \mathrm{c}$, No. 9, p. 112-114; Sobór Watykański II, ${ }^{3} 1986$ b, No. 25, p. 555-556; Chenu M.D., 1966, passim; Rabczyński P., 2005, p. 71-72).

Thus, the end of the Public Revelation does not restrict the role of the Church to passive investigation into the past. On the contrary, as the entity which interprets and substantiates the Revelation, the Church keeps conveying and explaining It in the contemporary context. According to the Catechism of the Catholic Church:

»The Christian economy, therefore, since it is the new and definitive Covenant, will never pass away; and no new public revelation is to be expected before the glorious manifestation of our Lord Jesus Christ. Yet even if Revelation is already complete, it has not been made completely explicit; it remains for Christian faith gradually to grasp its full significance over the course of the centuries" (21997, No. 66, p. 23).

\section{Definition of Marian apparitions}

As discussed above, Marian apparitions are classed as private revelations. In order to define them, it may be useful to invoke the synthetic fragment included in the Catechism of the Catholic Church:

»Throughout the ages, there have been so-called 'private' revelations, some of which have been recognized by the authority of the Church. They do not belong, however, to the deposit of faith. It is not their role to improve or complete Christ's definitive Revelation, but to help live more fully by it in a certain period of history. Guided by the Magisterium of the Church, the sensus fidelium knows how to discern and welcome in these revelations whatever constitutes an authentic call of Christ or his saints to the Church. Christian faith cannot accept 'revelations' that claim to surpass or correct the Revelation of which Christ is the fulfilment« (21997, No. 67, p. 23).

An analysis of source literature and statements made by the Magisterium allows the author to offer an integral definition of the phenomena in question. According to this definition, Marian apparitions are visions occurring in post-Apostolic times, experienced by chosen individuals and imbued with a supernatural message directed at a larger group. They are aimed at bringing into actuality the Divine Revelation in a given historical period (Perrella S. M., 2009, p. 25-28; Ratzinger J., 2000, p. 47-51; Adnès P., 1992, p. 1189-1193; 
Bolewski J., 1994, p. 52-56; Granat W., 1960, p. 147-150; Guitton J.-J., et Antier J.-J., 1993; Laurentin R., 1994, p. 22-67; Laurentin R., 1973; Rusecki M., 1994a, p. 35-44; Schmaus M., 1989, p. 27; Seweryniak H., 2001, p. 101-107; Volken L., 1961; Rabczyński P., 2005, p. 73).

This raises the question of the anthropological character of those visions. Usually, they take the form of apparitions-manifestations, visible to the seer. Those revelations involve an interior vision (visio imaginativa) which fundamentally differs from sensory or spiritual visions (visio sensibilis, visio intellectualis). It should be emphasised that the seer perceives an interior vision as a sensory phenomenon. Thus, it is not a figment of imagination but an authentic experience of transcendent (supernatural) reality, imperceptible to the senses but accessible through signs and symbols (Ratzinger J., 2000, p. 49; Rusecki M., 1994a, p. 38). To paint a full picture, it should be added that interior visions, while preserving their specific objectivism, are not free from subjective factors. Man (the subject of a vision) perceives the revealed substance (the object of a vision) as well as his individual potential and cognitive abilities permit. His way of seeing is also informed by other subjective factors: emotionality, attitude, moral stance, sensibility, general cultural conditions. Thus, based on the experience of himself and the surrounding world, the subject becomes - in a sense - a co-creator of the object (Mucci G. M., 2000, p. 38-46; Laurentin R., 1994, p. 42-47; Perrella S. M., 2009, p. 26-27; Zdybicka Z. J., ${ }^{2} 1993$, p. 171-197).

The message is an important part of any private revelation. God, who is the source (Author) of every authentic revelation, does not manifest Himself in history just for the sake of making an appearance but always for the good of man; His ultimate goal is human salvation. Therefore, the message which accompanies epiphanic signs is - like in the Old and the New Testament - a constitutive element of the revelations, and even a criterion for discerning their credibility (Rusecki M., 1994a, p. 39; Rabczyński P., 2005, p. 73-75).

Messages of Marian apparitions usually involve certain admonitions and calls which foster the spiritual growth of the faithful, remind them of the basic truths of the Gospel, and show them in a new light. They do not involve new content, absent from the teachings of the Church, but frequently present it in a new manner or a new form. Note that although the message is directed at the chosen seers, it is not imparted only and exclusively for their personal gain. By the agency of the seers, the message is meant to reach a larger group, sometimes even the entire Church community so that - like the charismata and other supernatural gifts - it enriches the entire people of God or its substantial part (Rusecki M., 1994a, p. 40-41; Adnès P., 1992, p. 1193). Even though the Church does not oblige the faithful to accept their veracity or believe their content, the course of history shows that many a time the revelations contributed to the renewal and the animation of religious life, giving new impulses for the ministry (Parzych K., 2005). 


\section{Criteria for discerning the credibility of Marian epiphanies}

Genuine Marian apparitions are recognised by way of discerning signs of their authenticity. The discernment requires a set of criteria helpful in gaining moral certitude that a given epiphenomenon is of supernatural origin, and thus is not a subjective figment of a deranged imagination, a hallucination, a symptom of illuminism or a hoax. It is impossible to provide proof of its veracity and gain absolute certainty - neither in this nor any other case which involves a transcendent reality. However, it is possible to consider certain signs as arguments for the credibility of those apparitions (The issue of the criteria is further discussed in: Perrella S. M., 2009, p. 9-51; Laurentin R., 1994, p. 52-67; Idem, 1996, p. 19-21; Rusecki M., 1994a, p. 44-50; Seweryniak H., 2001, p. 104-106).

The entity which discerns the authenticity of all private revelations is the Magisterium of the Church, which acts with great prudence and circumspection. The statement of approval is usually not expressed explicitly but in a negative way, in a formula that the phenomena in question do not contradict the Public Revelation and their supernatural character cannot be excluded. According to René Laurentin (1994, p. 24), from mid-20 ${ }^{\text {th }}$ century onwards, the Church tends to be restrictive towards private revelations, in line with the rule that a mistake made out of extreme severity is preferable to excessive openness which could undermine the infallibility of the Church.

The discernment of the credibility of Marian epiphanies and other private revelations is based on the document issued by the Congregation of the Doctrine of the Faith on 25 February 1978, approved by Pope Paul VI and entitled Norms regarding the manner of proceeding in the discernment of presumed apparitions or revelations (The document was issued ad interim and sub secreto for the use of competent authorities of the Church. The history of statements made by the Magisterium on private revelations is presented in: Pawluk T., 1977, p. 80-89). The verification of the epiphenomena in question involves a seven-part procedure: 1 ) obtaining credible information on the facts; 2 ) investigating the content of the message within the scope of its conformity with orthodox Church teachings; 3) establishing a medical diagnosis on the health of the seers; 4) examining the intellectual and moral condition of the seers, as well as their spiritual and sacramental life; 5) recognising the spiritual fruits borne by the revelations; 6 ) recognising the miracles, if any; 7) stating the judgment of the Church (Perrella S. M., 2009, p. 28-29; Cardinale G., 2008, p. 15).

Salvatore Maria Perrella (2009, p. 28, 30) notes that this canonical and theological procedure shall be reviewed and modernised. The changes are necessary primarily in order to increase the involvement of secular persons in the ecclesial discernment of the authenticity of the revelations, an alteration which would bolster the charismata of the laity in the spirit of the Constitution $\mathrm{Lu}$ men Gentium adopted by the Second Vatican Council (No. 12). 
Upon consideration of the modern theological research, this article lists four main criteria for discerning the credibility of Marian epiphanies: a) Christological and ecclesiological reference; b) good fruits of the revelations; c) miracles and other supernatural phenomena; d) credibility of people experiencing the revelations. In the next sections, those criteria will be discussed and applied to Marian apparitions in Gietrzwałd to demonstrate their credibility (Rabczyński P., 2018, p. 200-207).

\section{a) Christological and ecclesiological reference}

Considering the history of the Revelation and its concurrent salvation history, only those revelations should be deemed genuine which, pointing to Christ and His Church, are complemented by those two realities. The content of Marian visions and apparitions cannot contradict the divine economy of salvation, fulfilled through and in Christ, with the saving intermediation of the Church. Therefore, all Marian epiphanies whose messages cannot be reconciled with the teachings contained in the Scripture and the Tradition should be unambiguously rejected and declared false. The same applies to the epiphanies which make no reference to the religious sphere at all, focusing solely on the secular themes related to politics, economics, etc. The authenticity of the phenomena in question may also be dismissed on account of their excessively emphasised - by their spectacularity, sensationality, extravagance - phenomenal aspects which would obscure the religious content. In general, it may be assumed without a doubt that any content contradictory to faith and morals constitutes a negative criterion which rules out the veracity of the revelation.

When applying this criterion to the Gietrzwałd apparitions, it should be noted that Bishop Philipp (Filip) Krementz of Warmia (1819-1899) (Chłosta J., 2008 , p. 414) conducted a thorough investigation into the events. He demanded a report from the local parish priest, the Rev. Augustyn Wiechsel (1830-1909) (Jakubowski Z., 1977, p. 147-152) - an avid enthusiast of the revelations and their exponent (The content of the report sent to Bishop Krementz on $8 \mathrm{Au}-$ gust 1877, see: Obłąk J., 1977, p. 41-46). Furthermore, on 18 September 1877, the bishop set up a committee tasked with discerning the authenticity of the revelations. The committee comprised two eminent authority figures: the Rev. August Karau, Dean of Olsztyn, and the Rev. Edward Stock, Dean of Barczewo (The bishop's writ whereunder the committee was formed, see: Obłąk J., 1977, p. 47). The visionaries and other witnesses were questioned. The committee reached the conclusion that the events in Gietrzwałd must have had a real basis (The report of the Bishop's Committee on the revelations in Gietrzwałd, see: Obłąk J., 1977, p. 47-65). Other emissaries of the bishop, learned theologians - the Rev. Augustyn Kolberg, Vice-Provost of the Theological Seminary in Braniewo (The account of the Rev. A. Kolberg, see: Obłąk J., 1977, p. 65-69) and the 
Rev. Franciszek Hipler, Provost of the same Seminary ([Hipler F.], 2017) - had appreciation and approval for both the seers and the messages they communicated. Bishop Krementz himself visited Gietrzwałd on 4 and 5 September 1877, observed the seers and conversed with them. Highly impressed by the events in Gietrzwałd, the head of the diocese acted with adequate prudence by expressing his favourable opinion, not explicitly, but indirectly, by allowing for the publication of a book penned by the Rev. Hipler, released on 21 November 1877 and entitled: Objawienia Matki Boskiej w Gietrzwałdzie dla ludu katolickiego podtug urzędowych dokumentów spisane [Revelations of the Mother of God in Gietrzwałd described for the Catholic people as recorded in official papers]. The bishop noted that the content of the book was in no part contradictory to the Catholic doctrine of faith and morals (Pawluk T., 1977, p. 91). As mentioned in the introduction, on 11 September 1977, Marian epiphanies in Gietrzwałd received official Church approval from Bishop Józef Drzazga of Warmia.

Excluding a range of particular issues which require further studies and not addressed in this paper for the lack of space, it may be asserted with full certitude that the analysis of the source material, relevant to the object, content and message of the revelations in question, confirms the religious character of the Gietrzwałd events and their conformity to the Public Revelation. The Marian epiphanies evince clear Christological and ecclesiological references, discernible with the use of theological hermeneutics (Rabczyński P., 2011, p. 248-263). The main ideas communicated to the seers by the Mother of God, encapsulated in three sentences: I am the Blessed Virgin Mary Immaculately Conceived; I wish you recite the rosary every day; Do not be sad for I will always be with you and the call to sobriety, fully fit into the divine economy of salvation as its reminder and actual manifestation at a specific historical stage (Pawluk T., 1977, p. 93-95). The message of Gietrzwałd - a call for conversion, repentance, fervent prayer of the rosary, and sobriety - is Evangelical par excellence. It strengthens the faith of the Church in the Merciful Father who sends his Son to complete the work of redemption through His suffering, pervaded with love to every man. Mary, appearing to the girls as a caring Mother, Immaculately Conceived, suffering from sin and the advancement of evil, teaches obedience to God the Father and shows the way to regain the lost fullness of humanity in Christ (Parzych K., 2005, p. 127-137).

The discussed apparitions contain no new religious truths. They are only a reminder of the vital requirements of the Gospel, the urgency of living by the instructions of Jesus Christ and the Church (Jezierski J., 2003, p. 156). Marian epiphanies in Gietrzwałd are in no part contradictory to Christian faith and morals. Finally, they fully meet the credibility criterion of Christological and ecclesiological reference. 


\section{b) Good fruits of the revelations}

Fruits borne by Marian apparitions are an important criterion for discerning their credibility. In a way, Christ Himself pointed to this argument in his warning against false prophets: By their fruit you will recognise them (Mt. 7:16, the first half). The arguments for the veracity of Marian apparitions or visions include conversions, a rise in piety, thriving sacramental life, the initiation of merciful works and the outpouring of the charismata imparted by the Holy Spirit: joy, peace, harmony, agreement, mutual understanding. However, if the revelations fill the seers with pride, bring chaos and unrest, disrupt the community, and cause a schism in the Church, they shall be deemed false. It should be added that for the indicated good fruits to have probative value, they should be permanently related to specific revelations and thus testify to the intensification of God's grace in the designated place.

The first positive effects of the events in Gietrzwałd could be observed in the conduct and the attitude of the visionaries themselves. Initial fear and uncertainty soon gave way to joy at meeting the Immaculately Conceived. People around the girls noticed a rise in their piety, but also their composure, concentration in prayer, simplicity and modesty in fulfilling their daily chores. Because of their visions, the seers experienced a state of rapture and a desire for holiness. Thus, it may be asserted that there was a clear change in their spiritual life, as confirmed by their decision to enter the Company of the Daughters of Charity of Saint Vincent de Paul. Both seers completed their postulancy in Chełm and then the novitiate in the motherhouse of the Company in Paris. They took their first vows on 2 February 1889.

For unknown reasons, Sister Augustyna Justyna Szafryńska left the Congregation in 1897, after fourteen years. She married and moved to Gelsenkirchen in northern Westphalia, where she suffered poverty and lived in an unhappy marriage. Her correspondence showed that she missed the Congregation and the monastic life. Her date of death remains unknown (Tomczyk B. et Ryłko S., 1999, p. 66-67).

Sister Stanisława Barbara Samulowska, having spent 11 years in the capital of France, was sent to serve the poor in Guatemala. At first, she engaged in pedagogical work with young sisters as the directress of the novitiate. Then, she served among the sick at the hospitals in Antigua, Quetzaltenango and the capital of Guatemala. As a superior of the sisters, she proved to be a good organiser, acting with energy and sound judgment, highly devoted to the sick and other sisters. Furthermore, Sister Stanisława cared for poor children and adolescents, providing them with spiritual and material support. Her last year of life was marked with horrible suffering which she bore with good humour. She died of cancer at the Central Hospital in Guatemala, on 6 December 1950. She never boasted about her revelations, holding them in her heart as the greatest 
secret. She fulfilled the charism of her Company faithfully, keeping her focus on serving Christ in the poor and the suffering. She spread the devotion to the Blessed Virgin Mary. Sister Stanisława was a happy person, always smiling, radiating internal peace and devoted to God. Others were edified by her attitude: trusting and surrendering to His will. She could read the signs of time and the intentions of the Divine Providence revealed to her in certain situations. Sister Stanisława was a true witness of Christ in her times. Currently, her beatification process is underway (Rabczyński P., 2006, p. 555-562).

The Rev. Augustyn Weichsel (2017, p. 92-93), parish priest of Gietrzwałd at the time of the revelations, initially treated the reports of the visionaries with a great deal of prudence. However, in time, he became more and more convinced of their authenticity. Moved by the rise of piety among his parishioners and the growing pilgrimage movement, in his letter from 2 August 1883 he described the fruits of Marian epiphanies in the following words:

»Although the peace and quiet of our retreat was greatly disturbed by the substantial influx of the pilgrims, by no means solicited on our part, I openly confess with gratitude to God that against all false rumours spreading in the world, I observe great progress in the morality of conduct and the fervour of serving God in my parish. There is extensive evidence for that, including: the growing number of members in the Brethren of the Saint Sobriety, continuing great diligence in attending services and communal prayers, frequent reception of the Holy Sacraments, particular adoration of the Holy Rosary, recited fervently not only at the church, but also at home, multiple conversions of the heretics, and finally the fondness for maidenhood which made many virgins enter monasteries: and this progress in true piety is manifest not only in the parish of Gietrzwałd, but also in more remote areas and beyond Prussian borders, as admitted even by the enemies of the Church.«

Thus, upon consideration of the source material gathered directly after the revelations ended and in the years that followed, it may be asserted that Marian epiphanies in Gietrzwałd bore blessed fruits of spiritual and moral renewal among the faithful, contributing to the renaissance of religious life in the region of Warmia and beyond. The Beautiful Lady reminded people of the essential requirements contained in the Gospel of Her Son. She called for conversion, repentance, prayer and sobriety.

At this point, there is one more important permanent fruit of revelations to be discussed. As mentioned above, Blessed Honorat of Biała read the Gietrzwałd message of Mary as a sign which inspired him to establish a new monastic family: Servant Sisters of the Most Blessed Virgin Mary Immaculate. The close relationship between the founding of the congregation and the Marian epiphanies from Gietrzwałd is confirmed by the Blessed Honorat himself. It was a well-known fact among the general public, and is still remembered by the sisters themselves, who have special reverence for Our Lady of Gietrzwałd and fulfil her message (Wójcik M., 1977, p. 365-377). 
The impact of revelations, their permeation into the daily piety and forms of worship, did not end in the $19^{\text {th }}$ century. It has continued ever since. There are fluctuations in the interest with the content communicated by the visionaries, but the interest itself is stable. Nowadays, pilgrims still flock to Gietrzwałd, all mysteries of the rosary are recited each day, the sick and the addicted - first and foremost the alcoholics - come to participate in retreats and formative meetings. Many are healed, both spiritually and bodily (Obłąk J., 1977, p. 32-38; Pawluk T., 1977, p. 98-101; Tomczyk B. et Ryłko S., 1999, p. 21-22; Leniec A. et Bielawny K., 2005, p. 138-210). Thus, the criterion of good fruits borne by the Gietrzwałd revelations is met and confirms their supernatural character.

\section{c) Miracles and supernatural phenomena}

Miracles are a special sign pointing to the credibility of Marian apparitions. In general, the sites of authentic Marian epiphanies witness miraculous events which testify to the fulfilment of God's saving work in a given time and place. It should be emphasised that apart from a range of particular issues relevant to the motivating aspect of a miracle in Christianity, miraculous events fulfil revelatory, soteric and faith-generating functions. On one hand, they presume faith, on the other - they are a call for faith, serving to strengthen and animate it (Granat W., 1960, p. 147-148). According to Marian Rusecki (1994a, p. 48), a miracle confirms the authenticity of a private revelation not by its physical aspects (phenomenal, perceptible) but by its content (supernatural sense) which is one with the private revelation's message (its supernatural sense) which, in turn, evinces a connection to the Public Revelation.

The most frequent supernatural events that accompany authentic private revelations are miraculous healings. They occur as a result of accepting a Marian epiphany through the intercession of the Mother of God. The miracles should be instantaneous and permanent, defying medical explanation (Theillier P., 2005, p. 33-40). The medical committee issuing an opinion on the miraculous healing starts the examination procedure by confirming that a grave disease had been contracted. Then, the committee tries to exclude the existence of any psychiatric pathologies and investigates whether the healing was instantaneous, direct, unexpected, fully permanent and definitive, not resulting from earlier medical treatment. The final verdict states that the healing is inexplicable by the laws of medicine and biology (Lambertenghi Deliliers G., 2005, p. 9).

Apart from the miracles, signs that may point to the credibility of Marian epiphanies include other supernatural phenomena of corporeal character (e.g. levitations, ecstasies), emotional (e.g. exaltations), cognitive (e.g. discerning good and evil, infused knowledge). For the mystical and special phenomena joined with the revelations to have probative value, they need a meticulous 
evaluation conducted by specialists in medical sciences, psychological sciences and the theology of spirituality (Castellano J. C., 2000, p. 133-164. For information on the canonical perspective on miracles, see: Misztal H., ${ }^{2} 2003$, p. 86-94).

Did miracles and other supernatural phenomena occur in Gietrzwałd under the influence of Marian apparitions? It is difficult to answer the question unequivocally. Even the Rev. Augustyn Weichsel in his report to Bishop Krementz of 8 August 1877 declared that he had received many accounts of healings wrought by the Beautiful Lady. The parish priest was convinced of the veracity of those cures but could not confirm them officially for a lack of adequate documentation. The members of the Bishop's Committee and other priests send by the diocesan head to Gietrzwałd made similar statements. Although various miraculous events and cures were reported and then examined, none of the healed could document the testimony with necessary medical records ([Hipler S.], 2017, p. 67-75; Obłąk J., 1977, p. 39-40).

The Sanctuary of Gietrzwałd, kept by the Canons Regular of the Lateran since the end of the Second World War, has records of reported healings in a book entitled: Ksiega task $i$ uzdrowień otrzymanych za przyczyna NMP w Gietrzwatdzie [The Book of Graces and Cures Received through the Blessed Virgin Mary in Gietrzwałd]. Created in 1962 by the Rev. Franciszek Węglarczyk, the book comprises statements of people given from 1947 onwards. Regrettably, none of the reported cases have been subjected to a canonical examination conducted by a designated medical and theological committee. The subjective certitude of the faithful of their healings and received graces is confirmed by the multiplicity of gifts and votive offerings made at the Sanctuary of Gietrzwałd. One could also invoke moral miracles experienced by the pilgrims who visited the apparition site. First and foremost, those include conversions, freeing from evil and sin, spiritual consolation. Those miracles touch on the internal sphere of man, equally important as the corporeal aspect (Leniec A., 2005, p. 178-185).

Both miraculous healings and other graces received at the apparition site and in other locations through the intercession of Our Lady of Gietrzwałd cannot be regarded as an objective sign pointing to the credibility of the Marian epiphanies in Gietrzwałd. That is because none of them were subjected to canonical examination and officially declared inexplicable in the light of the contemporary medical knowledge.

\section{d) The credibility of people experiencing revelations}

Needless to say, people experiencing revelations should have specific qualities which would substantiate the message contained in the epiphenomena. Certainly, the health condition of seers must be examined, particularly their mental condition, emotionality, susceptibility to suggestions, pathological tendencies, as well as their honesty, sincerity, transparency and stability of 
conduct and speech which rule out the possibility that the seers seek publicity, fame or material gain. Of paramount importance is the obedience of seers to spiritual guides and the authority of the Magisterium of the Church, even when faced with temporary negative verdicts; for God often requires dedication and sacrifice from seers.

Irrespectively of the foregoing expatiations, one cannot deny that private revelations might be experienced by the mentally ill, people living in sin, or even non-believers. The history of the Divine Revelation, enshrined on the pages of the Scripture, teaches us great humility in regard to the oftentimes incomprehensible decisions and choices of the Divine Wisdom within the scope of persons, places and time of imparting grace (Rusecki M., 1994a, p. 46).

As noted by Zenomena Płużek (1994, p. 146-150. Ibidem: psychological criteria for differentiating between true and false mystical experiences), discerning the credibility of people experiencing revelations, visions, ecstasies, or other mystical experiences is - psychologically - an arduous task since the phenomena in question have a very complex structure. Thus, it is required to consider multiple psychological and physiological factors accompanying the supernatural phenomena, as well as the personal maturity, susceptibility to suggestions, emotionality and intelligence of the seers. Equally important are the motivations of people experiencing revelations. Keep in mind that neither medicine nor psychology have adequate tools to designate a religious experience as supernatural. It is the theologians who decide on the supernatural qualities of phenomena.

At the wish of Bishop Krementz, the visionaries of Gietrzwałd underwent medical examinations. Doctor August Dittrich of Dobre Miasto examined the girls three times on 5 and 6 September 1877; doctor Poschmann of Orneta - twice, on 7 September; doctor A. Sonntag of Olsztyn once, also on 7 September. Each doctor conducted the examination separately. It should be noted that the first two were Catholics while the third one was an Evangelical. The doctors unanimously asserted that the girls were healthy, both physically and mentally, and that there was no history of mental or neurotic illness in their families. Furthermore, doctors Dittrich and Poschmann declared that during the recitation of the rosary, the visionaries remained in some state of rapture, accompanied by the loss of control over some muscles and their numbness. Those findings were not confirmed by doctor Sonntag (See: doctors' accounts in: [Hipler S.], 2017, p. 45-51. Pawluk T., 1977, p. 91).

The committee set up by Bishop Krementz on 18 September 1877 and charged with discerning the authenticity of the revelations was made up of the Rev. August Karau and the Rev. Edward Stock. Their report described Justyna Szafryńska and Barbara Samulowska as humble, simple, natural, plain-spoken, modest and polite, accepting their visions in a natural, even naive manner, with no fancy airs or dwelling on the extraordinary character of the events. They an- 
swered the questions asked by the investigators decidedly, with no hesitation. During the revelation, they fell in the state of ecstasy and temporarily stopped responding to external stimuli. According to the testimony of the parish priest, the Rev. Weichsel, and their acquaintances, they were normal, obedient, willing to work, amiable and simply pious. Although they came from poor families, they were not looking for material gain. Hence, the Bishop's Committee declared that their testimonies should be accepted as true (Obłąk J., 1977, p. 48-49).

It should be added that at the time directly preceding the revelations, the girls made preparations for the First Holy Communion and attended religious education classes with diligence. Although they failed to make great progress at school, they were quite proficient in Polish and German. The investigation revealed no confabulation or traces of their stories being coordinated. Finally, no external pressure on the seers and no attempt at influencing their testimonies was detected ([Hipler S.], 2017, p. 34-36).

Upon consideration of the source material, it may be concluded that both visionaries, Justyna Szafryńska and Barbara Samulowska, were fully credible. Both their health condition and their morals were beyond reproach, as was their conduct with regard to the revelations they experienced. Medical opinions and morality certificates issued by the Bishop's Committee and the local parish priest are reliable in this respect and seem sufficient. The events of Gietrzwałd could not be a figment of infantile imagination since the intellectual level of the visionaries would not have allowed them for such a fabrication. Besides, the seers did not have sufficient general and religious knowledge to tell untruths. The message of Gietrzwałd far surpassed their abilities of intellectual understanding of what was happening. In conclusion, it has to be asserted that the sign pointing to the credibility of the seers fully confirms the revelations themselves.

\section{Conclusions}

Marian apparitions are aimed at bringing into actuality the Divine Revelation in a given historical period. Although the Public Revelation reached its culmination and fullness in the Word Incarnate and the Revelation history ended with the passing of the last living Apostle, it has continued and remained available throughout history thanks to the Church. The Church - the sacrament of salvation - makes present the epiphanic signs which allow man to become incorporated in the stream of salvation. What is more, the entire ecclesial community is obliged to modernise the revealed reality so that men of any time, in their own realities, could consciously and freely read the Divine Revelation and respond to it with an act of faith. Marian apparitions throughout history makes 
us realise the indispensability of interpreting the Public Revelation. The interpretations may not add anything to the Divine Revelation or change its content. However, they have an important role to play as signals that the Revelation should be modernised. Owing to Marian apparitions, the incomprehensible truths of faith are easier to grasp, while some truths whereof the people of God are generally unaware become - in a manner of speaking - re-discovered and popularised. The content of Marian apparitions usually boils down to a call for conversion, repentance or prayer. Thus, it provides an important impulse for Christian renewal, a return to Evangelical fervour and holiness (Rabczyński P., 2011, p. 261-262).

René Laurentin (1996, p. 9-10) is right to emphasise that for man, Marian apparitions are necessary signs of God's presence and closeness. And though the signs are subjective, the faith of a Christian often grows weak without them. Marian epiphanies cement Christian hope, embolden man in the face of weakness. They are providential signs which serve the prophetic function of the people of God.

Marian apparitions naturally inspire Marian devotion which, properly understood, is, in its most profound sense, a contemplation of the Mystery of the Incarnation. The devotion is expressed through acts of admiration, reverence, thanksgiving, supplication for intercession, but above all: by following Her example (Courth F., 1999, p. 77-87). It helps to accept Jesus as the only Redeemer and Saviour, opening our eyes to His presence in the history of every man and the history of the world.

The remarks on Marian apparitions in general apply to Marian epiphanies in Gietrzwałd as well. A theological analysis of the four criteria for discerning the credibility of epiphenomena in question (Christological and ecclesiological reference; good fruits of the revelations; miracles and other supernatural phenomena; credibility of people experiencing the revelations) in the context of the events that transpired in Gietrzwałd in 1877 indicates that the apparitions are fully credible.

It should be reiterated that the revelations in Gietrzwałd, as fully credible - which this paper aimed to prove on the basis of theological research - were officially approved by virtue of the ordinary Pastoral Office of the Warmian bishop. They made great impact on the religiosity of people in the Warmian diocese and beyond. The revelations triggered a mass pilgrimage movement which has continued and kept growing ever since. For the faithful from Warmia, Masuria, Pomerania and Greater Poland, Gietrzwałd became a little Lourdes, a capital of the Blessed Mother Immaculately Conceived. Marian epiphanies in Gietrzwałd led to new priestly initiatives such as a family rosary and a sobriety movement. Furthermore, they created a rise in priestly, monastic and missionary ordinations. The Gietrzwałd Sanctuary is a place of moral transformation where the spirit of faith becomes renewed and strengthened. 


\section{Reference}

Achremczyk Stanisław, 2002, Dzieje Gietrzwałdu do 1945 roku, Wydawnictwo MG, Olsztyn.

Adnès Pierre, 1992, Révélations privées, in: René Latourelle et Rino Fisichella (ed.), Dictionaire de théologie fondamentale, Bellarmin/Cerf, Montréal - Paris, p. 1189-1193.

Bartnik Czesław S., 1999, Dogmatyka katolicka, Vol. 1, Redakcja Wydawnictw Katolickiego Uniwersytetu Lubelskiego, Lublin.

Bartoszewski Gabriel, 1977, Nieopublikowany rękopis Stugi Bożego O. Honorata Koźmińskiego, kapucyna, pt.: Chwała Jezusowi przez Maryję Niepokalanie Poczętą (Opis objawień w Gietrzwatdzie), Studia Warmińskie XIV, p. 349-363.

Bartoszewski Gabriel et Roland Prejs (ed.), 1993, Błogosławiony Honorat Koźmiński. (Pokłosie beatyfikacji), Warszawa.

Bolewski Jacek, 1994, Teologiczne aspekty jawień maryjnych, in: Kazimierz Pek (ed.), Objawienia Maryjne. Drogi interpretacji, Wydawnictwo Księży Marianów, Warszawa, p. 52-68.

Cardinale Gianni, 2008, Tempi e criteri per "giudicare« le apparizioni, Intervista con Monsignor Angelo Amato di Gianni Cardinale, Avvenire 9.7.2008, p. 15.

Castellano Jesús C., 2000, Fenomenologia della vita spirituale conspeciale riferimento ai fenomeni preternaturali. Mistica Cristiana e fenomeni mistici, in: Studio della Congregazione per le Cause dei Santi, Roma, p. 133-164.

Catechism of the Catholic Church, ${ }^{2} 1997$, Libreria Editrice Vaticana, Città del Vaticano.

Chenu Marie-Dominique, 1966, Peuple de Dieu dans le monde, Cerf, Paris.

Chłosta Jan, 2008, Filip Krementz, in: Stanisłąw Achremczyk (ed.), Poczet Biskupów Warmińskich, Ośrodek Badań Naukowych im. Wojciecha Kętrzyńskiego w Olsztynie, Olsztyn, p. 413-420.

Courth Franz, 1999, Mariologia - Maryja, Matka Chrystusa, in: Wolfgang Beinert (ed.), Mariologia. Eklezjologia. Podręcznik teologii dogmatycznej, Wydawnictwo M, Kraków, p. 43-205.

De Candido Luigi M., 2004, Manifestazioni straordinarie per il bene del popolo di Dio, Credere oggi 142, No. 4, p. 77-89.

Drzazga Józef, 1977, Dekret nr 2100/77. Gietrzwałd, 11 września 1977 r, Studia Warmińskie XIV, p. 5.

Fisichella Rino, 1992, Introduzione alla teologia fondamentale, Piemme, Casale Monferrato.

Granat Wincenty, 1960, Teologiczna wiara, nadzieja i mitość, Towarzystwo Naukowe Katolickiego Uniwersytetu Lubelskiego, Lublin.

Guitton Jean-Jacques et Antier Jean-Jacques, 1993, Les pouvoirs mystérieux de la foi. Signes et merveilles, Librairie Académique Perrin, Paris.

[Hipler Franciszek], 2017, Objawienia Matki Boskiej w Gietrzwałdzie. Przedruk wydania z 1883 r., Warmińskie Wydawnictwo Diecezjalne, Olsztyn.

Jakubowski Zbigniew, 1977, Ksiadz Augustyn Weichsel - proboszcz gietrzwałdzki w czasie objawień 1877 roku, Studia Warmińskie XIV, p. 147-152. 
Jezierski Jacek, 2003, Posłowie: Znaczenie objawień gietrzwałdzkich, in: Jacek Jezierski et al. (ed.), Maryjne orędzie z Gietrzwałdu, Częstochowa - Gietrzwałd, p. 156.

Kasjaniuk Grzegorz, 2017, Gietrzwatd. 160 objawień Matki Bożej dla Polski i Polaków - na trudne czasy, Fronda, Warszawa.

Kongregacja Nauki Wiary, 2001, Deklaracja Dominus Iesus o jedyności i powszechności zbawczej Jezusa Chrystusa i Kościoła, No. 5-8, in: Marian Rusecki (ed.), Wokót deklaracji Dominus Iesus, Towarzystwo Naukowe Katolickiego Uniwersytetu lubelskiego, Lublin, p. 9-33.

Kongres Mariologiczny i Maryjny, 1977, Rezolucja, Warmińskie Wiadomości Diecezjalne, No. 32, p. 246.

Kopiczko Andrzej, 2003, Objawienia gietrzwałdzkie w świetle zbiorów Archiwum Archidiecezji Warmińskiej w Olsztynie, in: Jacek Jezierski et al. (ed.), Maryjne orędzie z Gietrzwałdu, Polskie Towarzystwo Mariologiczne, Częstochowa Gietrzwałd, p. 29-37.

Kopiczko Andrzej, 2008, JózefDrzazga, in:Stanisław Achremczyk (ed.), Poczet Biskupów Warmińskich, Ośrodek Badań Naukowych im. Wojciecha Kętrzyńskiego w Olsztynie, Olsztyn, p. 457-464.

Koźmiński Honorat, 2017, Przesłanie z Gietrzwatdu. Chwała Jezusowi poprzez Maryję Niepokalanie Poczęta, Fronda, Warszawa.

Lambertenghi Deliliers Giorgio, 2005, Wprowadzenie, in: Katolickie Stowarzyszenie Lekarzy Włoskich, Lekarz wobec cudu, Księgarnia Świętego Wojciecha, Poznań, p. 8-10.

Latourelle René, 1992, Révélation, in: René Latourelle et Rino Fisichella (ed.), Dictionaire de théologie fondamentale, Bellarmin/Cerf, Montréal-Paris, p. 1134-1189.

Laurentin René, 1973, Vraies et fausses apparitions dans l'Église, Lethielleux, Paris.

Laurentin René, 1994, Wspótczesne objawienia Najświętszej Maryi Panny, Exter, Gdańsk.

Laurentin René, 1996, Jak rozpoznać znak dany przez Boga? Vox Domini, Katowice.

Ledwoń Ireneusz S. et Rusecki Marian, 2002, Objawienie Boże, in: Marian Rusecki et al. (ed.), Leksykon Teologii Fundamentalnej, Wydawnictwo M, LublinKraków, p. 859-871.

Leniec Anna, 2005, Laski i uzdrowienia w sanktuarium gietrzwałdzkim, in: Katarzyna Parzych (ed.), Orędzie gietrzwałdzkie wczoraj $i$ dziś, Warmińskie Wydawnictwo Diecezjalne, Olsztyn, p. 178-185.

Leniec Anna et Bielawny Krzysztof, 2005, Sanktuarium gietrzwałdzkie dziś, in: Katarzyna Parzych (ed.), Orędzie gietrzwatdzkie wczoraj i dziś, Olsztyn, Warmińskie Wydawnictwo Diecezjalne, p. 138-210.

Misztal Henryk, 2003², Prawo kanonizacyjne, Wydawnictwo Diecezjalne Sandomierz, Lublin.

Mucci Giandomenico M., 2000, Rivelazioni private e apparizioni, Elledici-La Civiltà Cattolica, Torino-Roma.

Nowak Władysław, 1977, Historia obrazu i kultu Matki Boskiej Gietrzwałdzkiej, Studia Warmińskie XIV, p. 109-134. 
Obłąk Jan, 1957, Kościót na Warmii w okresie „Kulturkampfu”, Ateneum Kapłańskie, No. 2, p. 203-217.

Obłąk Jan, 1977, Objawienia Matki Boskiej w Gietrzwałdzie. Ich treść i autentyczność w opinii współczesnych (W stulecie objawień 1877-1977), Studia Warmińskie XIV, p. 7-73.

Parzych Katarzyna (ed.), 2005, Orędzie gietrzwałdzkie wczoraj i dziś, Warmińskie Wydawnictwo Diecezjalne, Olsztyn.

Parzych Katarzyna, 2005, Objawienia gietrzwałdzkie na tle innych objawień maryjnych, in: Katarzyna Parzych (ed.), Orędzie gietrzwałdzkie wczoraj i dziś, Olsztyn, p. 127-137.

Pawluk Tadeusz, 1977, Stosunek Kościoła do objawień prywatnych ze szczególnym uwzględnieniem wydarzeń gietrzwałdzkich, Studia Warmińskie XIV, p. 75107.

Pawluk Tadeusz, 1979, Człowiek charyzmatyczny we wspólnocie kościelnej na przykładzie stosunku Kościoła do objawień prywatnych, in: Lucjan Balter (ed.), Człowiek we wspólnocie Kościoła, Akademia Teologii Katolickiej, Warszawa, p. 284-298.

Perrella Salvatore M., 2009, Mariofanie w dziś Kościoła i świata. Aspekty wybrane, in: Teofil Siudy et Grzegorz M. Bartosik (ed.), Wokót objawień maryjnych. Polskie poktosie XXII Międzynarodowego Kongresu Mariologiczno-Maryjnego w Lourdes (4-8 IX 2008), Polskie Towarzystwo Mariologiczne, Częstochowa, p. 9-51.

Płużek Zenomena, 1994, Psychologiczne aspekty objawień, in: Kazimierz Pek (ed.), Objawienia maryjne. Drogi interpretacji, Wydawnictwo Księży Marianów, Warszawa, p. 144-151.

Rabczyński Paweł, 2005, Objawienia prywatne, in: Katarzyna Parzych (ed.), Orędzie gietrzwałdzkie wczoraj $i$ dziś, Warmińskie Wydawnictwo Diecezjalne, Olsztyn, p. 68-79.

Rabczyński Paweł, 2006, Stuga Boża Siostra Barbara Stanistawa Samulowska. Życie i działalność, Ateneum Kapłańskie, No. 3, p. 555-562.

Rabczyński Paweł, 2011, Hermeneutyka teologiczna mariofanii, in: Jacek Jezierski, Katarzyna Parzych-Blakiewicz (ed.), Matka Boża w wierze, kulcie, teologii $i$ sztuce. Perspektywa regionalna $i$ uniwersalna, Warmińskie Wydawnictwo Diecezjalne, Olsztyn, p. 248-263.

Rabczyński Paweł, 2018, Hermeneutyka teologiczna objawień gietrzwałdzkich, Teologia w Polsce, No. 12, 2, p. 193-213.

Rahner Karl, 1987, Podstawowy wyktad wiary, Instytut Wydawniczy Pax, Warszawa.

Ratzinger Joseph, 1970, Wprowadzenie w chrześcijaństwo, Wydawnictwo Znak, Kraków.

Ratzinger Joseph, 2000, Komentarz teologiczny do trzeciej tajemnicy fatimskiej, L'Osservatore Romano, Polish edition, No. 9, p. 47-51.

Rusecki Marian, 1994a, Kryteria „objawień prywatnych”, in: Kazimierz Pek (ed.), Objawienia Maryjne. Drogi interpretacji, Wydawnictwo Księży Marianów, Warszawa, p. 35-51. 
Rusecki Marian, 1994b, Wiarygodność chrześcijaństwa, Vol. 1, Z teorii teologii fundamentalnej, Towarzystwo Naukowe Katolickiego Uniwersytetu Lubelskiego, Lublin.

Schmaus Michael, 1989, Wiara Kościoła, Vol. 1, Objawienie - inicjatywa Boża oczekujaca odpowiedzi człowieka: wiary, Gdańsk - Oliwa.

Schmitz Josef, 1991, La rivelazione, Queriniana, Brescia.

Seckler Max, 1981, Dei Verbum religiose audiens: Wandlungen im christlichen Offenbarungsverständnis, in: Jakob J. Petuchowski et Walter Strolz (ed.), Offenbarung im jüdischen und christlichen Glaubensverständnis, Freiburg, p. 214-236.

Seweryniak Henryk, 2001, Świadectwo i sens, Płocki Instytut Wydawniczy, Płock.

Sobór Watykański II, ${ }^{3} 1986 a$, Konstytucja Dei verbum, in: Sobór Watykański II, Konstytucje. Dekrety. Deklaracje, Pallotinum, Poznań, p. 350-362.

Sobór Watykański II, ${ }^{3} 1986 b$, Konstytucja Gaudium et spes, in: Sobór Watykański II, Konstytucje. Dekrety. Deklaracje, Pallotinum, Poznań, p. 537-620.

Sobór Watykański II, ${ }^{3} 1986 c$, Konstytucja Lumen gentium, in: Sobór Watykański II, Konstytucje. Dekrety. Deklaracje, Pallotinum, Poznań, p. 105-166.

Theillier Patrick, 2005, Czy w aktualnej medycynie jest miejsce na cuda?, in: Katolickie Stowarzyszenie Lekarzy Włoskich, Lekarz wobec cudu, Księgarnia Świętego Wojciecha, Poznań, p. 33-40.

Tomczyk Bronisław et Ryłko Stefan, 1999, Siostra Miłosierdzia Barbara Stanisława Samulowska wizjonerka z Gietrzwałdu i inne osoby obdarzone łaską objawień, Instytut Teologiczny Księży Misjonarzy, Kraków.

Uroczystości maryjne w Gietrzwałdzie, 1968, Warmińskie Wiadomości Diecezjalne, No. 23, p. 86-93.

Volken Laurent, 1961, Les révélations dans l'église, Salvator, Mulhouse.

Weichsel Augustyn, 2017, Dodatek do drugiego wydania, in: [Hipler Franciszek], Objawienia Matki Boskiej w Gietrzwałdzie. Przedruk wydania z 1883 r., p. 92-93.

Wójcik Maria, 1977, Objawienia matki Bożej Gietrzwałdzkiej a Zgromadzenie Sióstr Stużek Najświętszej Maryi Panny Niepokalanej z Mariówki (1878), Studia Warmińskie XIV, p. 365-377.

Zdybicka Zofia J., ${ }^{2} 1993$, Człowiek $i$ religia. Zarys filozofii religii, Towarzystwo Naukowe Katolickiego Uniwersytetu Lubelskiego, Lublin. 


\section{Paweł Rabczyński* \\ Vjerodostojnost marijanskih ukazanja. Kontekst Gietrzwałd (Poljska) \\ Sažetak}

Godine 2017. navršila se 140. obljetnica Marijinih ukazanja u Gietrzwałdu, malom selu u južnoj Warmiji na sjeveru Poljske. Dana 11. rujna 1977. godine ukazanja u Gietrzwałdu dobila su službeno odobrenje Katoličke crkve. Poruka koju Majka Božja upućuje vidiocima može se sažeti u tri rečenice: »Ja sam bezgrješno začeta Blažena Djevica Marija«; »Želim da molite krunicu svaki dan«; »Nemojte biti tužni jer ću uvijek biti s vama.« Marijanska ukazanja, klasificirana kao takozvana privatna objava, usmjerena su na otkrivenja božanske stvrnosti u nekom povijesnom razdoblju. Sadržaj marijanskih ukazanja obično se svodi na poziv za obraćenje, pokajanje ili molitvu. Stoga pruža važan poticaj za kršćansku obnovu, povratak evanđeoskom žaru i svetosti. Uzimajući u obzir suvremena teološka istraživanja, u ovom su članku navedena četiri glavna kriterija za prepoznavanje vjerodostojnosti marijanskih ukazanja: a) kristološka i crkvena referenca; b) dobri plodovi otkrivenja; c) čuda i druge natprirodne pojave; d) vjerodostojnost ljudi koji doživljavaju ukazanja. Analizirajući pozvane znakove koji ukazuju na istinitost ukazanja, autor zaključuje da su marijanska ukazanja u Gietrzwałdu potpuno vjerodostojna.

Ključne riječi: javna objave, privatne objave, marijanska ukazanja, vjerodostojnost marijanskih ukazanja, kriteriji za prepoznavanje vjerodostojnosti marijanskih ukazanja.

\footnotetext{
* Prof. dr. sc. Paweł Rabczyński, Varmijsko i mazurijsko sveučilište, Teološki fakultet, Olsztyn; adresa: Ul. Hozjusza 15, 11-041 Olsztyn, Poljska; ORCID ID: 0000-0002-8732-7019.
} 